\title{
Long-term surviving cancer patients as a source of therapeutic TCR
}

\author{
Else Marit Inderberg ${ }^{1}$ (D) Sébastien Wälchli ${ }^{1}$ (]
}

Received: 15 September 2019 / Accepted: 28 December 2019 / Published online: 8 January 2020

(c) The Author(s) 2020

\begin{abstract}
We have established a platform for the isolation of tumour-specific TCR from T cells of patients who experienced clinical benefit from cancer vaccination. In this review we will present the rationale behind this strategy and discuss the advantages of working with "natural" wild type TCRs. Indeed, the general trend in the field has been to use various modifications to enhance the affinity of such therapeutic TCRs. This was done to obtain stronger T cell responses, often at the cost of safety. We further describe antigen targets and recent in vitro and in vivo results obtained to validate them. We finally discuss the use of MHC class II-restricted TCR in immunotherapy. Typically cellular anti-tumour immune responses have been attributed to CD8 T cells; however, we isolated mainly CD4 T cells. Importantly, these MHC class II-restricted TCRs have the potential to induce broad, long lasting immune responses that enable cancer control. The use of CD4 T cell-derived TCRs for adoptive immunotherapy has so far been limited and we will here discuss their therapeutic potential.
\end{abstract}

Keywords T cell receptor · Adoptive cell therapy $\cdot$ Vaccination $\cdot$ CD4 T cells $\cdot$ Cancer immunotherapy $\cdot$ PIVAC 19

\begin{tabular}{ll}
\multicolumn{2}{l}{ Abbreviations } \\
ACT & Adoptive cell therapy \\
CAR & Chimeric antigen receptor \\
hTERT & Human telomerase reverse transcriptase \\
MSI & Microsatellite instability \\
NY-ESO-1 & $\begin{array}{l}\text { New York esophageal squamous cell carci- } \\
\text { noma 1 }\end{array}$ \\
pMHC & Peptide MHC \\
TCR & T cell receptor \\
TGF $\beta$ RII & Transforming growth factor $\beta$ receptor II
\end{tabular}

This paper is a Focussed Research Review based on a presentation given at the Nineteenth International Conference on Progress in Vaccination against Cancer (PIVAC 19), held in Athens, Greece, 7th-9th June, 2019. It is part of a Cancer Immunology, Immunotherapy series of PIVAC 19 papers.

Else Marit Inderberg

elsin@rr-research.no

1 Department of Cellular Therapy, Department of Oncology, Oslo University Hospital, The Norwegian Radium Hospital, 0379 Oslo, Norway

\section{Introduction}

\section{Adoptive cell therapy}

Adoptive cell therapy (ACT) has been greatly enhanced when the injected $\mathrm{T}$ cells were genetically modified to express specific antigen receptors. In cancer therapy, two types have emerged, the natural $\mathrm{T}$ cell receptor (TCR) and the artificial Chimeric Antigen Receptor (CAR) [1]. The latter is a fusion of different protein domains, normally consisting of an antibody recognition domain on its external part which will be targeted towards a surface antigen. This extracellular domain is, through a transmembrane domain, connected to a series of signalling modules derived from the TCR signalling machinery. Despite the recent success and approval of CAR therapy for haematological malignancies [2] treatment of solid tumours still represents a challenge [3].

TCR therapy may have certain advantages over CARs for attacking solid tumours such as the number of targets available. Indeed, TCRs could in principle recognize any protein expressed by a cell, because all proteins are processed which in turn generates peptides that will be loaded on Major histocompatibility complex (MHC) class I and II molecules, whereas CAR recognition is restricted to surface molecules, limiting the tumour-specific pool of target antigens available. Furthermore, TCR recognition is highly subtle, and a 
single amino acid change on the target peptide can trigger the effector function of the TCR. Hence, peptides presented on MHC molecules can be derived from mutated proteins, rendering the recognition cancer-specific, an attribute that -although not impossible- is challenging to achieve with an antibody. Another argument in favour of TCR is that these molecules can be more sensitive to lower antigen densities on the target cell surface compared to CAR [4]. Direct comparisons of TCR and CAR are difficult because of differences in the ligands recognized and antigen. When Harris et al. [5] compared TCR $\alpha \beta$ heterodimers and single-chain TCRs coupled to CAR signalling tails, both recognizing the same peptide-MHC (pMHC) complexes, they demonstrated that CARs were much less sensitive than TCR to lower pMHC densities, but induced higher cytokine secretion. Finally, although the cytokine response generated by classical CAR molecules upon stimulation is often far more intense than what is observed with TCRs, recent data demonstrated that lower CAR-derived T-cell stimulation might improve clinical outcome [6, 7]. In this perspective TCRmodified T cells can be seen as "soft" living drugs, yet able to generate serious side effects $[8,9]$ compared to CAR-T and, if well calibrated, they should represent the solution of choice for solid tumour-based ACT.

\section{Isolating TCRs from vaccinated patients}

The isolation of therapeutic TCRs has been a technical challenge. Firstly, because interesting $T$ cells isolated from the blood or the tumour are never pure, and therefore require selection and expansion. Secondly, although the TCR sequence identification has benefitted from technological advances $[7,8]$, the validation procedures following the expression and testing of the TCR are still costly and time consuming. As previously mentioned, the signal detected upon TCR stimulation normally gives a weaker cytokine response compared to that of a CAR construct [10]. However, weaker signal observed in vitro does not preclude good clinical efficiency, rather the contrary as exemplified by recent studies with lower affinity $[6,7]$. In other words, our in vitro methods of TCR stimulation may lead to an underestimate of their efficacy in vivo. Consequently, this has driven an effort to manufacture supranatural TCRs through affinity maturation [11], murinization [12] or modification of the TCR structure to stabilize it (reviewed in [13]). TCR affinity increased beyond the physiological range comes with the risk of creating novel molecules with unpredictable binding specificities to structurally related peptide sequences from different antigens, creating off-target toxicity [8, 9]. Moreover, TCR variants were tested and the existence of a TCR affinity-related activation threshold was demonstrated both in vitro [14] and in vivo [15]. Here the authors of the two studies proposed that this threshold marked the limit between epitope recognition and autoimmunity. It was further shown that enhancing the peptide affinity, thus modifying the binding threshold on the peptide side, had similar deleterious effect on the in vivo potency of the TCR [16]. Together these reports suggest that TCRs with normal affinity, or unenhanced TCR, might be more optimal and safer for TCR-based therapy. For these reasons, we generally consider the manipulation of TCRs to be too hazardous and unpredictable to be exploited as a living drug. We have therefore implemented a therapeutic TCR platform which only produces "natural" TCRs (Fig. 1). Blood from long-term surviving cancer patients who experienced clinical benefit after treatment with therapeutic cancer vaccines was collected. To find tumour-reactive TCRs, the T cells were isolated and analysed for their pMHC specificity against autologous presenting cells [17-21]. We see three critical advantages of using these TCRs: (1) they were not toxic to the patient who carried them, (2) they were selected in a human thymus, and (3) these TCRs were likely part of the immune response involved in the survival of the patients. Furthermore, these patients can be a source of discovery of TCRs with specificities for alternative antigens; indeed we have previously isolated TCRs targeting tumour antigens other than the vaccine. This suggests that the immune response against these new epitopes was generated by epitope spreading which occurred during the immune attack of the tumour and shown to correlate with clinical response [21]. T-cell clones isolated from these patients can be tested and compared to find the optimal candidates for TCR therapy. The criteria of selection are several, with the most important being (1) a focus on frequently expressed MHC alleles for a broad population coverage, and (2) public rather than personal cancer antigens. Isolating such TCRs and transferring them to new cells will only transfer the properties of the TCR with its specificity and affinity for the target whereas the avidity of the original $\mathrm{T}$ cell clone comprising more than the TCR properties will of course not be transferred. The New York esophageal squamous cell carcinoma 1(NY-ESO-1) is by far the most frequently targeted antigen in clinical trials of TCR therapy to date [22]. TCRs specific for this antigen have been tested in several clinical trials ([23-25] and unpublished clinical studies) with variable success. Still, NY-ESO-1 is a perfect target: it is not expressed in normal tissues and is present in different tumour types. In addition, hotspots of antigenic peptides inducing CD4 and CD8 T-cell responses have been well characterized [26, 27]. Recently, the team of D. Baltimore reported on a procedure to isolate the most efficient candidates directly from patient blood [28]. It will be interesting to follow the clinical progression of these TCRs.

We have previously reported on the isolation of a public neoantigen-specific TCR, Radium-1 [29, 30]. Here microsatellite instable (MSI)+ colorectal cancer patients had been vaccinated with a long peptide covering a frequent 


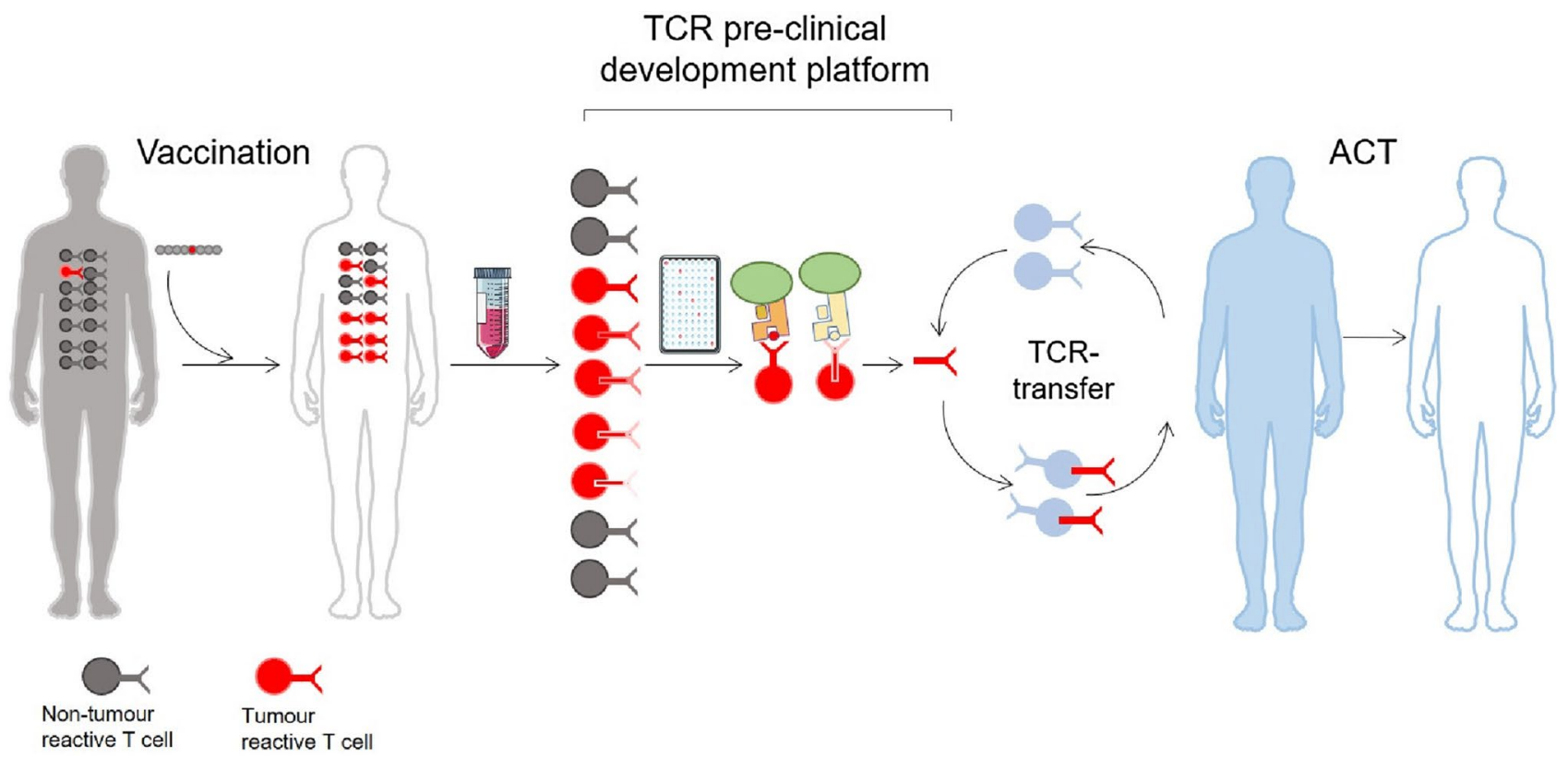

Fig. 1 Pre-clinical TCR development platform. Successful vaccination of cancer patients gives rise to an increased frequency of tumour specific $\mathrm{T}$ cells. After isolation of the clones and characterization of

Transforming growth factor $\beta$ receptor II (TGF $\beta$ RII) frameshift mutation as a result of the dysfunctional DNA mismatch repair mechanisms ([31] and Inderberg and Gaudernack et al., unpublished data). From one of these patients, a TCR specific for a known HLA-A*02:01 epitope was isolated [29]. The TCR, named Radium-1, is currently in clinical testing (NCT03431311). We also isolated two MHC class II-restricted TCRs from two other vaccinated patients in this study ([32] and Inderberg, Wälchli et al., unpublished data) which shifted the focus of our development platform to CD4 T-cell derived TCRs due to the central role of CD4 $\mathrm{T}$ cells in anti-tumour immune responses.

\section{The rise of T helper TCRs}

Whereas cellular anti-tumour immune responses have typically been attributed to CD8 $\mathrm{T}$ cells, CD4 $\mathrm{T}$ cells play a critical role in tumour elimination and in the priming and maintenance of CD8 T-cell responses (recently reviewed in [33], Fig. 2). Moreover, CD4 T cells activate innate cells such as macrophages and NK cells to contribute to antitumour responses and can also have direct cytotoxic effect against tumour cells expressing MHC class II [34-36]. The use of MHC class II-restricted CD4 T cells for adoptive immunotherapy has been limited due to (1) a lack of wellcharacterized shared tumour antigens presented by MHC class II, (2) the majority of tumour cells being class II negative and therefore not directly presenting antigen to CD4 T cells, and (3) the lack of tools to evaluate CD4 TCR efficacy. their pMHC specificity, the TCR sequence is identified. After preclinical validation, these therapeutic TCRs are used to treat nonresponding MHC-matched patients

However, the use of CD4 T cells in ACT should also circumvent one of the common tumour escape mechanisms, which is the loss of MHC class I to prevent recognition by the immune system [37]. All clinical studies of TCR therapy published to date, except one [38], have used MHC class I restricted TCRs (recently reviewed in [39]). MHC class IIrestricted $\mathrm{CD} 4+\mathrm{T}$ cells are able to induce more robust and broader anti-tumor immune responses which could improve outcomes in cancer immunotherapy. One of the antigens we have focused on is human telomerase reverse transcriptase (hTERT) with several academic vaccination studies carried out [17-19, 40, 41]. This is a well characterized antigen which is almost universally expressed in cancer cells due to its essential role in unlimited cell growth, metastasis and expression in cancer stem cells (reviewed in [42]). One concern regarding this antigen has been that as an overexpressed tumour-associated antigen (TAA), it is also present at lower level in normal cells such as activated lymphocytes, stem cells and germ cells (reviewed in [42]).

Two MHC class I-restricted TCRs specific for hTERT have previously been published $[43,44]$. The HLA-A*02:01 restricted TCR was isolated from a vaccinated HLA transgenic mouse whereas the HLA-A*24:02 restricted TCR was isolated from healthy donor blood. Both were of high affinity and deemed safe by pre-clinical testing, but have not yet reached the clinic. We have, however, not been able to generate tumour-recognizing MHC class I restricted T cell clones against hTERT as the cells may commit fratricide, although there exists conflicting evidence for this [45, 46]. 
Fig. 2 CD4 T-cell anti-tumour responses. Tumour-specific CD4 T cells can activate and maintain CD8 $\mathrm{T}$ cell responses and can also induce tumour cell killing by activating tumourinfiltrating macrophages. Graphical elements adapted from Servier Medical Art repository (https://www.servi er.com)

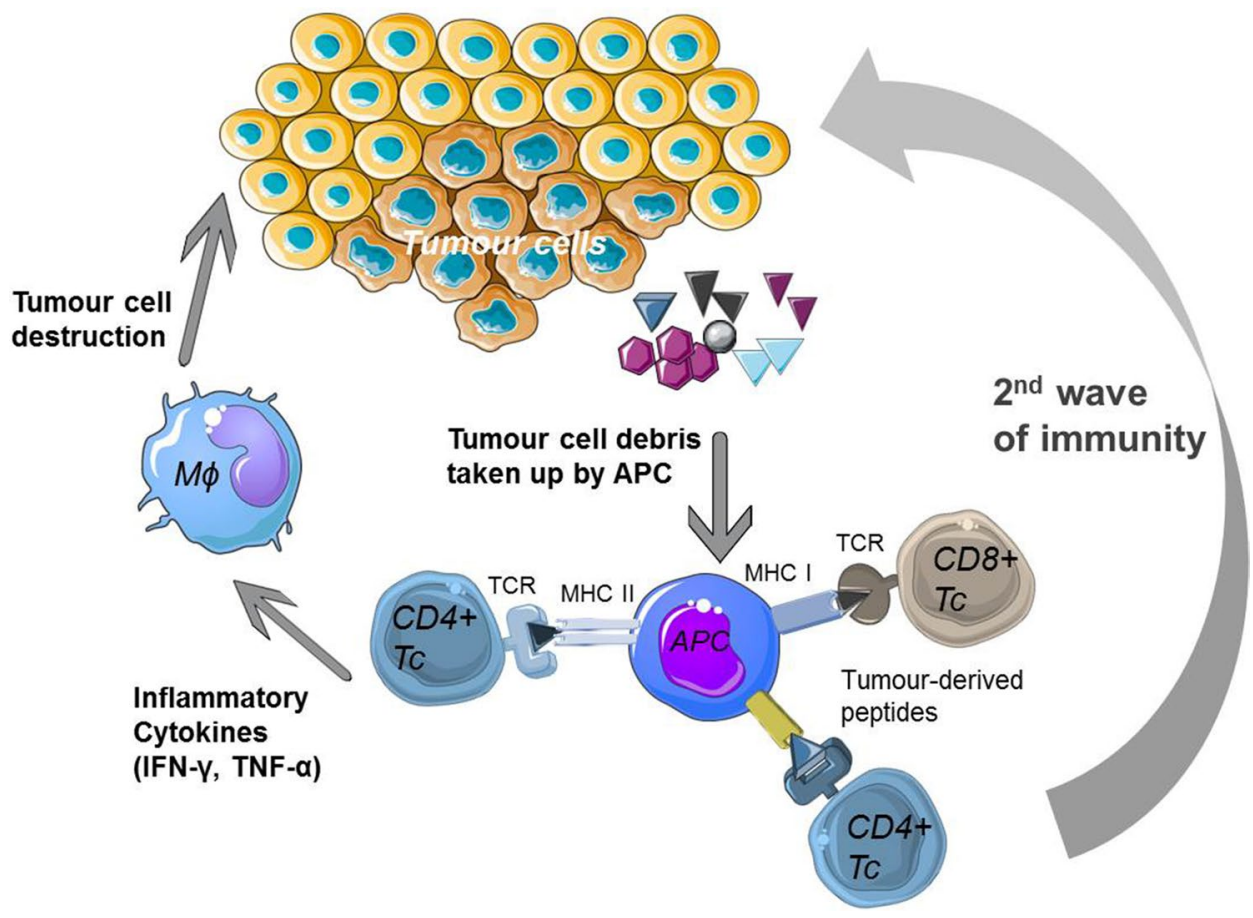

Thus, TAA can become dangerous as target for CD8 TCR due to the risk of "on-target, off-tumour toxicity". Since only a limited number of normal cells are MHC class II positive, it is tempting to speculate that a CD4 TCR might be less toxic against overexpressed TAA. In agreement with this, we reported that the patients carrying these hTERT-specific $\mathrm{T}$ cell clones performed well clinically and had no signs of toxicity. Bone marrow function was indeed monitored in long-term surviving lung cancer patients post vaccination without showing toxicity [18]. In addition, the presence of these hTERT-specific CD4 T cells after vaccination has been shown to correlate with enhanced survival of the patient $[19,20,40]$.

We have therefore focused on the development of nonmodified patient-derived hTERT-specific TCRs. From a long-term surviving pancreatic cancer patient, we have isolated an hTERT-specific TCR restricted to the very common allele HLA-DP4, which we named Radium-4, which demonstrated surprising qualities (Dillard et al., in revision), such as the capacity to directly eliminate MHC class II positive target cells loaded with peptide, but also to reduce tumour growth in a melanoma xenograft model. The TCR transfected and transduced $\mathrm{T}$ cells did not show any signs of fratricide or reactivity against normal cells.

We are also developing additional hTERT-specific TCRs recognising alternative hTERT epitopes after vaccinationinduced epitope spreading which are restricted to various HLA alleles [21]. These TCRs are isolated from several patients vaccinated with a hTERT peptide vaccine [21]. Developing CD4 T-cell based therapy comes with the technical challenge that although they can kill tumour cells, their primary mode of action is by engaging with other players in the immune system to orchestrate a broad attack of the tumour. This is impossible to fully reproduce in our in vitro models or in mouse xenograft models using immunodeficient animals. We therefore depend on demonstrating the direct killing effect or cytokine production, which is more circumstantial evidence for their activity, whereas we may be largely underestimating the effect this may have in humans if successfully implemented.

CD4 T-cell derived TCRs are also being developed against other antigens, including neoantigens such as the abovementioned TGF $\beta$ RII frameshift mutation found in MSI + colorectal and endometrial cancer. Two of the identified MHC class II restricted TCRs were shown to recognise the same mutation as our MHC class I restricted TCR [29, 30].

These TCRs, named Radium- 5 and -6 , were identified in patients from the same clinical vaccination trial (Inderberg, Gaudernack et al., unpublished data) and shown to efficiently redirect T cells [32]. Preliminary data from our in vivo xenograft model indicate that these TCRs could be as efficient at reducing tumour growth as their MHC class I restricted counterpart (Dillard, Wälchli and Inderberg et al., unpublished observations). The TCRs are restricted to frequently expressed MHC class II molecules and it could be interesting to also combine their use with the Radium-1 TCR.

Finally, the TCRs that we have identified so far do seem to be able to function without their CD8 or CD4 coreceptor. A good illustration was done when we expressed 
these TCRs in a cell line devoid of co-receptor, such as an NK cell line, the NK-TCR [47]. When we transduced our TCRs into NK92, which had been modified to overexpress human CD3, we observed that Radium-1 TCR was functional in this system, independently of the presence of CD8. Likewise, when we tested some of our CD4 T cellderived TCRs to generate NK-TCR cells, we observed that these cells killed MHC class II $^{+}$antigen presenting tumour cells (Mensali, Inderberg and Wälchli et al., unpublished data). These data suggest that vaccinated patient-derived TCR can function without co-receptors.

\section{Future perspectives}

TCR-based therapy also encounters hurdles for eradicating metastatic tumour due to the immunosuppressive tumour microenvironment (TME) or T cell exhaustion. There are several initiatives to remedy this by improving $\mathrm{T}$ cell trafficking through the modification of homing receptors [48-50], resistance to TGF- $\beta$ [51], modification or blocking of immune checkpoints [52]. Such strategies will likely be increasingly implemented in future clinical trials. Additionally, there are numerous therapy combinations that, if designed wisely, could have an impact on the efficacy of ACT, such as the combination with immune checkpoint blockade, post-transplant vaccination to improve T-cell persistence, and specific targeting of the TME immunosuppression. To date, few CD4 T-cell based therapies have been tested clinically [38, 53-55], but have shown clear evidence of clinical activity.

Combining HLA class I- and class II-restricted TCRs for T-cell redirection may also provide a more potent therapeutic effect in adoptive T cell therapy [56]. MHC class II-restricted TCRs may additionally have direct therapeutic value both in haematopoietic malignancies and in melanoma where tumour cells frequently express MHC class II. Importantly, CD4 T cells and MHC class II TCRs therefore have the potential to orchestrate broad and longlasting immune responses that enable cancer control.

Author contributions Both authors contributed equally to the writing of the manuscript.

Funding The research was supported by the Norwegian Research Council (Grant nos. 244388 and 254817) and the Norwegian Health Region South East (Grant nos. 2017075 and 2016006).

\section{Compliance with ethical standards}

Conflict of interest S Wälchli and EM Inderberg are inventors of the patent applications WO2017194555 and WO2019166463.
Open Access This article is licensed under a Creative Commons Attribution 4.0 International License, which permits use, sharing, adaptation, distribution and reproduction in any medium or format, as long as you give appropriate credit to the original author(s) and the source, provide a link to the Creative Commons licence, and indicate if changes were made. The images or other third party material in this article are included in the article's Creative Commons licence, unless indicated otherwise in a credit line to the material. If material is not included in the article's Creative Commons licence and your intended use is not permitted by statutory regulation or exceeds the permitted use, you will need to obtain permission directly from the copyright holder. To view a copy of this licence, visit http://creativecommons.org/licenses/by/4.0/.

\section{References}

1. Fesnak AD, June CH, Levine BL (2016) Engineered T cells: the promise and challenges of cancer immunotherapy. Nat Rev Cancer 16:566-581. https://doi.org/10.1038/nrc.2016.97

2. Jacoby E, Shahani SA, Shah NN (2019) Updates on CAR T-cell therapy in B-cell malignancies. Immunol Rev 290:39-59. https:// doi.org/10.1111/imr.12774

3. Mardiana S, Solomon BJ, Darcy PK, Beavis PA (2019) Supercharging adoptive $\mathrm{T}$ cell therapy to overcome solid tumor-induced immunosuppression. Sci Transl Med 11:eaaw2293. https://doi. org/10.1126/scitranslmed.aaw2293

4. Huang J, Brameshuber M, Zeng X, Xie J, Li QJ, Chien YH, Valitutti S, Davis MM (2013) A single peptide-major histocompatibility complex ligand triggers digital cytokine secretion in CD4(+) T cells. Immunity 39:846-857. https://doi.org/10.1016/j.immun i.2013.08.036

5. Harris DT, Hager MV, Smith SN et al (2018) Comparison of T cell activities mediated by human TCRs and CARs that use the same recognition domains. J Immunol 200:1088-1100. https:// doi.org/10.4049/jimmunol.1700236

6. Ying Z, Huang XF, Xiang X et al (2019) A safe and potent antiCD19 CAR T cell therapy. Nat Med 25:947-953. https://doi. org/10.1038/s41591-019-0421-7

7. Ghorashian S, Kramer AM, Onuoha S et al (2019) Enhanced CAR T cell expansion and prolonged persistence in pediatric patients with ALL treated with a low-affinity CD19 CAR. Nat Med 25:1408-1414. https://doi.org/10.1038/s41591-019-0549-5

8. Cameron BJ, Gerry AB, Dukes J et al (2013) Identification of a Titin-derived HLA-A1-presented peptide as a cross-reactive target for engineered MAGE A3-directed T cells. Sci Transl Med 5:197ra03. https://doi.org/10.1126/scitranslmed.3006034

9. Morgan RA, Chinnasamy N, Abate-Daga D et al (2013) Cancer regression and neurological toxicity following anti-MAGEA3 TCR gene therapy. J Immunother 36:133-151. https://doi. org/10.1097/CJI.0b013e3182829903

10. Baeuerle PA, Ding J, Patel E et al (2019) Synthetic TRuC receptors engaging the complete $\mathrm{T}$ cell receptor for potent anti-tumor response. Nat Commun 10:2087. https://doi.org/10.1038/s4146 7-019-10097-0

11. Linette GP, Stadtmauer EA, Maus MV et al (2013) Cardiovascular toxicity and titin cross-reactivity of affinity-enhanced T cells in myeloma and melanoma. Blood 122:863-871. https://doi. org/10.1182/blood-2013-03-490565

12. Bialer G, Horovitz-Fried M, Ya'acobi S, Morgan RA, Cohen CJ (2010) Selected murine residues endow human TCR with enhanced tumor recognition. J Immunol 184:6232-6241. https:// doi.org/10.4049/jimmunol.0902047

13. Merhavi-Shoham E, Haga-Friedman A, Cohen CJ (2012) Genetically modulating T-cell function to target cancer. Semin Cancer Biol 22:14-22. https://doi.org/10.1016/j.semcancer.2011.12.006 
14. Presotto D, Erdes E, Duong MN, Allard M, Regamey PO, Quadroni M, Doucey MA, Rufer N, Hebeisen M (2017) Fine-tuning of optimal TCR signaling in tumor-redirected CD8 T cells by distinct TCR affinity-mediated mechanisms. Front Immunol 8:1564. https ://doi.org/10.3389/fimmu.2017.01564

15. Zhong S, Malecek K, Johnson LA et al (2013) T-cell receptor affinity and avidity defines antitumor response and autoimmunity in T-cell immunotherapy. PNAS 110:6973-6978. https://doi. org/10.1073/pnas.1221609110

16. Corse E, Gottschalk RA, Krogsgaard M, Allison JP (2010) Attenuated $\mathrm{T}$ cell responses to a high-potency ligand in vivo. PLoS Biol 8(9):e1000481. https://doi.org/10.1371/journal.pbio.1000481

17. Bernhardt SL, Gjertsen MK, Trachsel S, Moller M, Eriksen JA, Meo M, Buanes T, Gaudernack G (2006) Telomerase peptide vaccination of patients with non-resectable pancreatic cancer: a dose escalating phase I/II study. Br J Cancer 95:1474-1482

18. Brunsvig PF, Aamdal S, Gjertsen MK et al (2006) Telomerase peptide vaccination: a phase I/II study in patients with nonsmall cell lung cancer. Cancer Immunol Immunother 55:15531564. https://doi.org/10.1007/s00262-006-0145-7

19. Kyte JA, Gaudernack G, Dueland S, Trachsel S, Julsrud L, Aamdal S (2011) Telomerase peptide vaccination combined with temozolomide: a clinical trial in stage IV melanoma patients. Clin Cancer Res 17:4568-4580. https://doi.org/10.1158/10780432.CCR-11-0184

20. Suso EM, Dueland S, Rasmussen AM, Vetrhus T, Aamdal S, Kvalheim G, Gaudernack G (2011) hTERT mRNA dendritic cell vaccination: complete response in a pancreatic cancer patient associated with response against several hTERT epitopes. Cancer Immunol Immunother 60:809-818. https://doi.org/10.1007/ s00262-011-0991-9

21. Inderberg-Suso EM, Trachsel S, Lislerud K, Rasmussen AM, Gaudernack G (2012) Widespread CD4+ T-cell reactivity to novel hTERT epitopes following vaccination of cancer patients with a single hTERT peptide GV1001. Oncoimmunology 1:670-686. https://doi.org/10.4161/onci.20426

22. Zhang J, Wang L (2019) The emerging world of TCR-T cell trials against cancer: a systematic review. Technol Cancer Res Treat 18:1533033819831068. https://doi.org/10.1177/15330 33819831068

23. Robbins PF, Kassim SH, Tran TL et al (2015) A pilot trial using lymphocytes genetically engineered with an NY-ESO1-reactive T-cell receptor: long-term follow-up and correlates with response. Clin Cancer Res. 21:1019-1027. https://doi. org/10.1158/1078-0432.CCR-14-2708

24. Robbins PF, Morgan RA, Feldman SA et al (2011) Tumor regression in patients with metastatic synovial cell sarcoma and melanoma using genetically engineered lymphocytes reactive with NY-ESO-1. J Clin Oncol 29:917-924. https://doi. org/10.1200/jco.2010.32.2537

25. Rapoport AP, Stadtmauer EA, Binder-Scholl GK et al (2015) NY-ESO-1-specific TCR-engineered T cells mediate sustained antigen-specific antitumor effects in myeloma. Nat Med 21:914921. https://doi.org/10.1038/nm.3910

26. Gnjatic S, Atanackovic D, Jäger E et al (2003) Survey of naturally occurring CD4+ T cell responses against NY-ESO-1 in cancer patients: correlation with antibody responses. PNAS 100:8862-8867. https://doi.org/10.1073/pnas.1133324100

27. Jager E, Chen YT, Drijfhout JW et al (1998) Simultaneous humoral and cellular immune response against cancer-testis antigen NY-ESO-1: definition of human histocompatibility leukocyte antigen (HLA)-A2-binding peptide epitopes. J Exp Med 187:265-270. https://doi.org/10.1084/jem.187.2.265

28. Bethune MT, Li XH, Yu J et al (2018) Isolation and characterization of NY-ESO-1-specific T cell receptors restricted on various MHC molecules. PNAS 115:E10702-E10711. https:// doi.org/10.1073/pnas.1810653115

29. Inderberg EM, Walchli S, Myhre MR, Trachsel S, Almasbak H, Kvalheim G, Gaudernack G (2017) T cell therapy targeting a public neoantigen in microsatellite instable colon cancer reduces in vivo tumor growth. Oncoimmunology 6:e1302631. https://doi.org/10.1080/2162402X.2017.1302631

30. Mensali N, Myhre MR, Dillard P, Pollmann S, Gaudernack G, Kvalheim G, Walchli S, Inderberg EM (2019) Preclinical assessment of transiently TCR redirected T cells for solid tumour immunotherapy. Cancer Immunol Immunother 68(8):12351243. https://doi.org/10.1007/s00262-019-02356-2

31. Markowitz S, Wang J, Myeroff L et al (1995) Inactivation of the type II TGF-beta receptor in colon cancer cells with microsatellite instability. Science 268:1336-1338. https://doi.org/10.1126/ science. 7761852

32. Mensali N, Grenov A, Pati NB et al (2019) Antigen-delivery through invariant chain (CD74) boosts CD8 and CD4 T cell immunity. Oncoimmunology 8:1558663. https://doi.org/10.1080/21624 02x.2018.1558663

33. Borst J, Ahrends T, Babala N, Melief CJM, Kastenmuller W (2018) CD4(+) T cell help in cancer immunology and immunotherapy. Nat Rev Immunol 18:635-647. https://doi.org/10.1038/ s41577-018-0044-0

34. Xie Y, Akpinarli A, Maris C, Hipkiss EL, Lane M, Kwon EK, Muranski P, Restifo NP, Antony PA (2010) Naive tumor-specific CD4(+) T cells differentiated in vivo eradicate established melanoma. J Exp Med 207:651-667. https://doi.org/10.1084/ jem.20091921

35. Quezada SA, Simpson TR, Peggs KS et al (2010) Tumor-reactive CD4(+) T cells develop cytotoxic activity and eradicate large established melanoma after transfer into lymphopenic hosts. J Exp Med 207:637-650. https://doi.org/10.1084/jem.20091918

36. Matsuzaki J, Tsuji T, Luescher IF et al (2015) Direct tumor recognition by a human CD4(+) T-cell subset potently mediates tumor growth inhibition and orchestrates anti-tumor immune responses. Sci Rep 5:14896. https://doi.org/10.1038/srep14896

37. Garrido F, Cabrera T, Aptsiauri N (2010) "Hard" and "soft" lesions underlying the HLA class I alterations in cancer cells: implications for immunotherapy. Int J Cancer 127:249-256. https ://doi.org/10.1002/ijc.25270

38. Lu YC, Parker LL, Lu T et al (2017) Treatment of patients with metastatic cancer using a major histocompatibility complex class II-restricted T-cell receptor targeting the cancer germline antigen MAGE-A3. J Clin Oncol 35:3322-3329. https://doi.org/10.1200/ JCO.2017.74.5463

39. Wolf B, Zimmermann S, Arber C, Irving M, Trueb L, Coukos G (2019) Safety and tolerability of adoptive cell therapy in cancer. Drug Saf 42:315-334. https://doi.org/10.1007/s40264-018-0779-3

40. Brunsvig PF, Kyte JA, Kersten C, Sundstrom S, Moller M, Nyakas M, Hansen GL, Gaudernack G, Aamdal S (2011) Telomerase peptide vaccination in NSCLC: a phase II trial in stage III patients vaccinated after chemoradiotherapy and an 8-year update on a phase I/II trial. Clin Cancer Res 17:6847-6857. https://doi. org/10.1158/1078-0432.CCR-11-1385

41. Vik-Mo EO, Nyakas M, Mikkelsen BV et al (2013) Therapeutic vaccination against autologous cancer stem cells with mRNAtransfected dendritic cells in patients with glioblastoma. Cancer Immunol Immunother 62:1499-1509. https://doi.org/10.1007/ s00262-013-1453-3

42. Zanetti M (2017) A second chance for telomerase reverse transcriptase in anticancer immunotherapy. Nat Rev Clin Oncol 14:115-128. https://doi.org/10.1038/nrclinonc.2016.67

43. Sandri S, Bobisse S, Moxley K et al (2016) Feasibility of telomerase-specific adoptive T-cell therapy for B-cell chronic 
lymphocytic leukemia and solid malignancies. Cancer Res 76:2540-2551. https://doi.org/10.1158/0008-5472.CAN-15-2318

44. Miyazaki Y, Fujiwara H, Asai H et al (2013) Development of a novel redirected T-cell-based adoptive immunotherapy targeting human telomerase reverse transcriptase for adult T-cell leukemia. Blood 121:4894-4901. https://doi.org/10.1182/blood-2012-11465971

45. Chen DY, Vance BA, Thompson LB, Domchek SM, Vonderheide RH (2007) Differential lysis of tumors by polyclonal T cell lines and $\mathrm{T}$ cell clones specific for hTERT. Cancer Biol Ther 6:19911996. https://doi.org/10.4161/cbt.6.12.5078

46. Wenandy L, Sorensen RB, Sengelov L, Svanethor IM, Straten P, Andersen MH (2008) The immunogenicity of the hTERT540548 peptide in cancer. Clin Cancer Res 14:4-7. https://doi. org/10.1158/1078-0432.CCR-07-4590

47. Mensali N, Dillard P, Hebeisen M et al (2019) NK cells specifically TCR-dressed to kill cancer cells. EBioMedicine 40:106-117. https://doi.org/10.1016/j.ebiom.2019.01.031

48. Almasbak H, Rian E, Hoel HJ, Pule M, Walchli S, Kvalheim G, Gaudernack G, Rasmussen AM (2011) Transiently redirected T cells for adoptive transfer. Cytotherapy 13:629-640. https://doi. org/10.3109/14653249.2010.542461

49. Craddock JA, Lu A, Bear A, Pule M, Brenner MK, Rooney CM, Foster AE (2010) Enhanced tumor trafficking of GD2 chimeric antigen receptor $\mathrm{T}$ cells by expression of the chemokine receptor CCR2b. J Immunother 33:780-788. https://doi.org/10.1097/ CJI.0b013e3181ee6675

50. Idorn M, Olsen M, Halldorsdottir HR, Skadborg SK, Pedersen M, Hogdall C, Hogdall E, Met O, Thor Straten P (2018) Improved migration of tumor ascites lymphocytes to ovarian cancer microenvironment by CXCR2 transduction. Oncoimmunology 7:e1412029. https://doi.org/10.1080/2162402x.2017.1412029
51. Kloss CC, Lee J, Zhang A et al (2018) Dominant-negative TGFbeta receptor enhances PSMA-targeted human CAR T cell proliferation and augments prostate cancer eradication. Mol Ther 26:1855-1866. https://doi.org/10.1016/j.ymthe.2018.05.003

52. Menger L, Sledzinska A, Bergerhoff K et al (2016) TALENmediated inactivation of PD-1 in tumor-reactive lymphocytes promotes intratumoral T-cell persistence and rejection of established tumors. Cancer Res 76:2087-2093. https://doi.org/10.1158/00085472.can-15-3352

53. Hunder NN, Wallen H, Cao J et al (2008) Treatment of metastatic melanoma with autologous CD4+ T cells against NY-ESO-1. N Engl J Med 358:2698-2703. https://doi.org/10.1056/NEJMoa0800 251

54. Tran E, Turcotte S, Gros A et al (2014) Cancer immunotherapy based on mutation-specific CD4+ T cells in a patient with epithelial cancer. Science 344:641-645. https://doi.org/10.1126/scien ce. 1251102

55. Assadipour Y, Zacharakis N, Crystal JS et al (2017) Characterization of an immunogenic mutation in a patient with metastatic triple-negative breast cancer. Clin Cancer Res 23:4347-4353. https://doi.org/10.1158/1078-0432.ccr-16-1423

56. Wälchli S, Myhre MR, Mensali N, Fåne A, Lislerud K, Kvalheim G, Gaudernack G,Inderberg EM (2017) Abstract 3773: tapping CD4 T cells for cancer immunotherapy. Cancer Res. https://doi. org/10.1158/1538-7445.am2017-3773

Publisher's Note Springer Nature remains neutral with regard to jurisdictional claims in published maps and institutional affiliations. 